Buana Sains Vol 20 No 1: 49 - 56, 2020

\title{
Karakteristik Tepung Ampas Tahu yang Difermentasi dengan Lactobacillus plantarum terhadap kandungan Daidzein, Glycitein, dan Genistein
}

\author{
Eka Fitasari dan Budi Santosa \\ Fakultas Pertanian, Universitas Tribhuwana Tunggadewi, Indonesia
}

\begin{abstract}
Animal feed should ideally be inexpensive and not competing with humans. Ampas know is a waste of the manufacture of tofu that contains protein and high energy. Its use has problems due to the existence of antinutrient and cannot be kept long. Lactobacillus Plantarum is a lactic acid (Gram-positive) bacteria used in the fermentation process to improve the quality of feed. The goal of fermentation is to remove the anti-nutrients that exist in the tofu pulp and increase the content of Isoflavone (Daidzin, Glycitein, and Genistein) and Isoflavone is a source of antioxidants important to growth. The study uses a Completely Randomized Design with 5 treatment of microbial culture concentrations of $1 \%, 5 \%, 10 \%, 15 \%$, and $20 \%(\mathrm{~V} / \mathrm{w})$, respectively repeated 3 times. The result of analyzes in the pulp of tofu fermentation suggests that fermentation by Lactobacillus Plantarum can increase the content of Daidzein, Glycitein, and genistein with the highest value resulting from the use of L. Plantarum $20 \%$ respectively $191.21+24.9 \mu \mathrm{g} / \mathrm{g}, 85.96 \mu \mathrm{g} / \mathrm{g}$, and $120.82 \mu \mathrm{g} / \mathrm{g}$. It can be concluded that the higher the use of the concentration of L. Plantarum in tofu pulp can increase the levels of isoflavone, so it is advisable to conduct research with the concentration of L. Plantarum higher in tofu pulp
\end{abstract}

Keywords: : Daidzin; glycitein; genistein; Lactobacillus Plantarum; tofu pulp.

\section{Pendahuluan}

Perkembangan populasi ternak setiap tahunnya meningkat, seiring dengan pertumbuhan jumlah penduduk. Begitu pula kebutuhan terhadap protein hewani, yang selama ini dipenuhi dari daging merah, daging ayam, telur, susu, dan sumber protein lainnya. Seiring dengan meningkatnya populasi ternak, maka meningkat pula kebutuhan pakan untuk menunjang kebutuhan ternak tersebut. Pakan ternak idealnya harus murah, tersedia di lingkungan peternakan, dan tidak bersaing dengan makanan manusia. Untuk mendapatkan pakan yang murah ini, peternak banyak menggunakan berbagai limbah pertanian dan limbah yang berasal dari industry pangan. Salah satunya adalah ampas tahu. Ampas tahu merupakan limbah padat sisa dari pengolahan tahu dan sudah tidak berguna lagi. Ampas tahu banyak digunakan oleh peternak sebagai pakan ternak, seperti pakan sapi, pakan babi, kelinci, dan komoditas ternak lainnya. Hal ini karena produksi tahu sendiri dilakukan setiap hari untuk menyukupi kebutuhan konsumen terhadap makanan tahu. Bentuk ampas tahu sendiri adalah basah, dengan kadar air 84.5\%, mengakibatkan bahan ini tidak dapat disimpan lama. Akan tetapi, ampas tahu ini memiliki kandungan nutrisi yang tinggi. Hasil analisa kandungan ampas tahu kering adalah Abu $4.37 \%$, PK 
Eka Fitasari dan Budi Santosa/ Buana Sains Vol 20 No $1: 49-56$

$23.63 \%$, serat kasar $20.16 \%$, lemak kasar $3.11 \%$, dan gross energy 4318.61 $\mathrm{kkal} / \mathrm{kg}$. Sedangkan menurut Santosa dkk, 2017) kandungan ampas tahu kering hasil fermentasi dengan EM-4 1\% adalah Abu 3.67\%, PK 14.39\%, SK 23,11\%, LK 20,2\%, dan GE 4862,75\$. Kandungan protein dan energy tersebut sudah mampu mencukupi kebutuhan nutrisi ayam, kelinci, maupun ternak ruminansia. Namun, khusu bagi ungags kandungan serat kasar yang tinggi dari ampas tahu kering yaitu sebesar 20 hingga 23\% \% dapat menghambat proses pencernaan ungags sehingga penggunaan ampas tahu dalam pakan juga harus dicampur dengan bahan-bahan pakan yang lain.

Daidzein, glycitein, dan genistein merupakan isoflavone yang terdapat dalam ampas tahu. Isoflavone sendiri merupakan suatu bahan yang berfungsi sebagai antioksidan. Penggunaan antioksidan dapat meningkatkan produksi daging dan kualitas daging dari ternak. Penelitian yang dilakukan oleh Jiang et al. (2007), penambahan 40 atau $80 \mathrm{mg}$ isoflavon per $\mathrm{kg}$ pakan dapat meningkatkan pertumbuhan ayam broiler jantan. Penggunaan isoflavone dalam pakan rata-rata meningkatkan pertumbuhan dan penambahan masa otot pada karkas ternak. Demikian pula pada penelitian Fitasari dan Thiasari (2019), bahwa penggunaan ampas tahu basah hasil fermentasi L.plantarum dalam pakan formulasi dapat menurunkan kandungan lemak pada daging kelinci. Isoflavon sendiri banyak diteliti karena memiliki kemampuan sebagai antioksidan dan phytoestrogenic. Isoflavone dihasilkan dari cabang jalur phenylpropanoid dan menghasilkan komponen yang disebut flavonoid dan ini sebagian besar terkandung pada tanman. Isoflavone memiliki aktivitas seperti hormone yang dapat menangkap reseptor estrogen (Kuiper et al., 1996).
Isoflavon memiliki kesamaan dengan hormone estrogen, pada manusia hormone ini dihasilkan di ovarium dan adrenal kortex ginjal yang berfungsi untuk proses pertumbuhan dan pemeliharaan tubuh. Menurut Setchell and Cassidy (1999), kedelai merupakan sumber isoflavone terbesar yaitu berkisar $118 \mathrm{mg} / 100 \mathrm{~g}$ hingga $306 \mathrm{mg} / 100 \mathrm{~g}$ ).

Dalam penelitian ini proses yang dilakukan adalah melakukan fermentasi menggunakan baketri asam laktat yaitu Lactobacillus plantarum. Menurut Galvez et al. (2007), bakteri asam laktat mampu menghasilkan enzim $\beta$-glukosidase, enzim ini terlibat dalam pengubahan glikosida isoflavon menjadi aglycon isoflavon Tujuannya dari penelitian ini adalah untuk mengukur perbedaan kandungan isoflavone yaitu pada kandungan daidzein, glycitein, dan genistin antara linbah ampas tahu yang tidak difermentasi dan dengan ampas tahu yang difermentasi dengan L. pantarum. Hasil penelitian Astuti and Zahra (2013), dialporkan bahwa fermentasi menggunakan bakteri asam laktat pada tahu dapat menghasilkan isoflavone.

\section{Metode Penelitian}

Penelitian ini dilaksanakan di Laboratorium Rekayasa Pangan Universitas Tribhuwana Tunggadewi Malang, Jawa Timur. Analisa kandungan isoflavon dilakukan Laboratorium biokimia Universitas Muhammadiyah Malang.

Bakteri Lactobacillus plantarum diperoleh dari Laboratorium Teknologi Hasil Pertanian Universitas Brawijaya, Indonesia. Media untuk Lactobacillus plantarum dibuat dengan cara merebus kentang yang sudah dikupas dan dipotong-potong ke dalam air aquades (perbandingan kentang $200 \mathrm{~g}$ : air 1000 $\mathrm{ml}$ ) hingga mendidih dan air menjadi 
keruh. Larutan kentang disaring menggunakan kain saring ke dalam Erlenmeyer, ditambahkan gula sebanyak $15 \mathrm{~g}$ sambil diaduk di atas kompor listrik. Selanjutnya Erlenmeyer ditutup menggunakan kapas + kertas coklat, diikat kuat menggunakan karet. Sebelum diinokulasi menggunakan Lactobacillus plantarum, semua peralatan dan media disterilisasi menggunakan otoklaf.

Percobaan fermentasi ampas tahu menggunakan perlakuan beberapa jenis mikroba dan konsentrasi yang berbeda disusun berdasarkan Rancangan Acak Lengkap dengan konsentrasi $\mathrm{P} 1=1 \%$, $\mathrm{P} 2=5 \%, \mathrm{P} 3=10 \%, \mathrm{P} 4=15 \% \mathrm{P} 5=$ $20 \%(\mathrm{v} / \mathrm{m})$ yaitu berdasarkan dari berat ampas tahu basah.

Pelaksanaan penelitian diawali dengan pembuatan ampas tahu yang difermentasi dengan Lactobacillus plantarum. Ampas tahu segar diperas airnya, dikukus selama 30 menit dan didinginkan. Ke dalam ampas tahu yang sudah dingin ditambahkan gula pasir sebanyak 1\%, susu skim 5\% (w/w), kemudian ampas tahu diberi Lactobacillus plantarum sesuai perlakuan. Semua bahan dicampur secara merata kemudian dimasukkan ke dalam plastik, diikat rapat hingga tidak ada gelembung udara dalam plastic. Selanjutnya ampas tahu fermentasi tersebut difermentasi dalam ruangan gelap dan ditutupi kresek hitam agar tidak terkena cahaya. difermentasi pada suhu kamar selama 5 hari.

Setelah lima hari fermentasi, plastik dibuka kemudian ampas tahu diambil dan dikeringkan ke dalam oven dengan suhu $60^{\circ} \mathrm{C}$ sampai kering. Setelah kering kemudian dihaluskan dan diayak. Selanjutnya dilakukan analisa kandungan isoflavon terhadap ampas tahu hasil fermentasi menggunakan HPLC dengan merk Shimadzu dengan SPD 20-A UVVis Detector.

Data-data dari parameter yang telah didapatkan hasil dari analisa di laboratorium dianalisis menggunakan analisis sidik ragam pada taraf $\alpha=5 \%$. Apabila hasil dari analisa sidik ragam menunjukkan beda nyata maka dilanjutkan dengan uji BNT( Gomes dan Gomes, 1984).

\section{Hasil dan Pembahasan}

Daidzein, Glycitein, dan genistein merupakan bentuk aglycone yang berasal dari Daidzin, glysitin, dan genistin. Perubahan ini terjadi selama proses degradasi makanan. Daidzin dan glysitin merupakan komponen organic alami dari phytochemical yang dikenal sebagai isoflavon. Daidzin merupakan7-Oglucoside dari daidzein dan dan glycitin merupakan 7-O glukosida dari glycitein. Demikian juga Genistin merupakan isoflavon dari kelas genistein dengan struktur genistein 7-glukosida. Ketika genistin yang berada dalam dalam makanan mulai didegradasi, maka genistin akan diubah menjadi bentuk aglycone yaitu menjadi genistein. Hal ini terjadi melalui proses hidrolisis dengan cara menghilangkan ikatan kovalen glukosa untuk membentuk genistein dan genistein merupakan bentuk komponen yang siap diserap dalam usus dan bentuk ini bertanggungjawab terhadap aktivitas biologis dari isoflavon.

Hasil fermentasi menggunakan Lactobacillus plantarum selama 5 hari proses inkubasi menunjukkan hasil yang ditampilkan pada Tabel 1. Hasil penelitian terhadap kadar daidzein, glycitein, dan genistein menunjukkan terdapat peningkatan pada ampas tahu yang difermentasi dibandingkan tanpa difermentasi. 
Eka Fitasari dan Budi Santosa/ Buana Sains Vol 20 No $1: 49-56$

Tabel 1. Kandungan isoflavone ampas tahu fermentasi dan tanpa fermentasi

\begin{tabular}{|c|c|c|c|}
\hline Perlakuan & $\begin{array}{l}\text { Daidzin } \\
(\mu \mathrm{g} / \mathrm{g})\end{array}$ & Glycitin ( $\mu \mathrm{g} / \mathrm{g})$ & Genistein $(\mu \mathrm{g} / \mathrm{g})$ \\
\hline $\begin{array}{l}\text { Kontrol (ampas tahu tidak } \\
\text { difermentasi) (P0) }\end{array}$ & 57.8 & 23.4 & 77.76 \\
\hline Konsentrasi mikroba 1\% (P1) & $142.37+20.6$ & $65.19+9.3$ & $90.06+13.4$ \\
\hline Konsentrasi mikroba 5\% (P2) & $186.71+19.3$ & $84.75+8.7$ & $106.95+29.7$ \\
\hline Konsentrasi mikroba 10\% (P3) & $164.66+43.7$ & $74.95+19.4$ & $104.33+26.9$ \\
\hline Konsentrasi mikroba 15\% (P4) & $146.81+8.6$ & $66.68+3.6$ & $92.49+5.6$ \\
\hline Konsentrasi mikroba 20\% (P5) & $191.21+24.9$ & $85.96+11.6$ & $120.82+15.5$ \\
\hline BNT & $p>0.05$ & $p>0.05$ & $p>0.05$ \\
\hline
\end{tabular}

Bakteri asam laktat menghasilkan enzim $\beta$-glikosidase, yang terlibat dalam perubahan glikosida isoflavon menjadi aglikon isoflavon (Galvez et al., 2007). Lactobacillus spp., Bacteriodes spp., dan Bifidobacterium spp memiliki enzim $\beta$ glukosidase endogenous. Berdasarkan hasil penelitian perlakuan fermentasi menggunakan L. plantarum, pada tepung ampas tahu hasil fermentasi, menghasilkan peningkatan terhadap kadar daidzein, glycitein, dan genistein dan konsentrasi tertinggi kandungan ketiga bahan tersebut diperoleh pada perlakuan P5 yaitu penggunaan $L$. plantarum 20\%. Hal ini disebabkan akibat proses hydrolysis yang dilakukan bakteri. Hal ini sesuai dengan pendapat Wang and Murphy (1994), kandungan isoflavon yang berasal dari produk olahan kedelai adalah dipengaruhi oleh perlakuan, yaitu perlakuan panas, proses memasak, hydrolysis oleh enzim, dan fermentasi. Hasil ini sejalan dengan penelitian Astuti dan Noviana (2013), penggunakan mikroba campuran konsentrasi 7.5\% (L.plantarum, L.acidophilus, L. mesenteroides) menghasilkan kadar isoflavon yang lebih tinggi.

Selama proses fermentasi pada ampas tahu akan memicu perubahan komponen phytochemical, menyebabkan perubahan bentuk isoflavon, terjadi hidrolisa protein dan mengurangi factor- faktor anti nutrisi yaitu dengan cara mengurangi kandungan tripsin inhibitor (Molteni et al, 1995, Zhu et al. 2005). Tripsin Inhibitor sendiri merupakan sejenis anti nutrisi yang terdapat dalam kedelai. Akibatnya akan meningkatkan aglycon isoflavon dan peptide-peptida aktif (Mejia and Lumen, 2006), dan secara langsung memberikan keuntungan terhadap kesehatan.

Hasil penelitian Rekha dan Vijayalaksmi (2010) melaporkan adanya perubahan pada konsentrasi $\beta$-glikosida dan aglycon isoflavon selama masa inkubasi. Semakin lama waktu inkubasi maka kadar aglicon semakin meningkat, demikian pula kadar daidzein dan genistein juga meningkat. Jenis mikroba paling mempengaruhi kadar aglycon. Hasil penelitian ini juga sejalan dengan hasil penelitian Chen et al. (2013), bahwa penggunaan probiotik pada susu kedelai mampu meningkatkan kadar genistein dan daidzein lebih tinggi dibandingkan kandungan daidzin dan genistin. Berdasarkan hasil uji menggunakan HPLC, dengan semakin tingginya konsentrasi L. pantarum maka semakin tinggi pula kadar daidzein, glycitein dan genistein. 
Eka Fitasari dan Budi Santosa/ Buana Sains Vol 20 No 1 : 49-56

\section{Kesimpulan}

Kesimpulan yang dapat diambil dari penelitian ini adalah bahwa semakin tinggi penggunaan konsentrasi Lactobacillus plantarum dalam ampas tahu dapat meningkatkan kadar daedzin, glycitein, dan genistein. Konsentrasi 20 $\%$ Lactobacillus plantarum dalam ampas tahu mampu memberikan hasil tertinggi terhadap kandungan daedzin, glycitein, dan genistein

\section{Daftar Pustaka}

Astuti, D. I., \& Noviana, Z. 2014. Optimization of fermented tofu with high isoflavone content through variation of inoculum percentages and ratios of lactobacillus plantarum, lactobacillus acidophilus, and leuconostoc mesenteroides. Journal of Mathematical and Fundamental Sciences, 45(3), 263273. https://doi.org/10.5614/ j.math.fund.sci.2013.45.3.5

Astuti, D. I. and Zahra N. 2013. Optimization of Fermented Tofu with Hingh Isoflavone Content through Variation of Inoculum Percentage and ratios of Lactobacillus plantarum, lactobacillus acidophilus, and Leuconostoc mesenteroide. J. Math. Fund Sci., vol 45 No 3 2013, $263-273$.

Chen, Y. M., Shih, T. W., Chiu, P. C., and Tsai, T. Y. 2013. Effects of lactic acid bacteria-fermented soy milk on melanogenesis in B16F0 melanocytes. Journal of Functional Foods volume 5, issue 1, January 2013, pages 395 - 405
Fitasari, E. dan N. Thiasari. 2019. Substitusi Ampas Tahu Terfermentasi Lactobacillus Plantarum Pada Formulasi Pakan Terhadap Kandungan Nutrisi Daging Kelinci Fase Grower. Journal of Tropical Animal Production. Vol 20, No. 2 pp. 127 134, Desember 2019

Gálvez, A., Abriouel, H., López, R. L., \& Omar, N. Ben. 2007. Bacteriocinbased strategies for food biopreservation. International Journal of Food Microbiology, 120(1-2), 51-70.

Jiang, S. Q., Jiang, Z. Y., Lin, Y. C., Xi, P. B., \& Ma, X. Y. 2007. Effects of soy isoflavone on performance, meat quality and antioxidative property of male broilers fed oxidized fish oil. AsianAustralasian Journal of Animal Sciences, 20(8), 1252-1257.

Kuiper, G. G., Enmark, E., PeltoHuikko, M., Nilsson, S. \& Gustafsson, J. A. 1996. Cloning of a novel receptor expressed in rat prostate and ovary. Proc. Natl. Acad. Sci. U.S.A. 93: 5925-5930.

Kuiper, G. G., Enmark, E., PeltoHuikko, M., Nilsson, S. \& Gustafsson, J. A. 1996. Cloning of a novel receptor expressed in rat prostate and ovary. Proc. Natl. Acad. Sci. U.S.A. 93: 5925-5930.

Molteni, A., Brizio - Molteni, L., and Persky, V. 1995. In Vitro Hormonal Effects of Soybean Isoflavones The Journal of Nutrition, Volume 125, Issue suppl_3, March 1995, Pages 751S-756S,

Rekha, C. R. ang G Vijayalakshmi. 2010. Bioconversion Of Isoflavone Glycosides To Aglycones, Mineral Bioavailability And Vitamin B 
Eka Fitasari dan Budi Santosa/ Buana Sains Vol 20 No 1 : 49-56

Complex In Fermented Soymilk By Probiotic Bacteria And Yeast. Journal of Applied Microbiology ISSN 1364-5072

Santosa, B., Fitasari, E., dan Suliana, G. 2017. Produksi Pakan Fungsional Mengandung Tiga Senyawa Bioaktif dari Ampas Tahu dengan Menggunakan Mikroba Effective Microorganism - 4 Dan Lactobacillus plantarum. Buana Sains Vol 17 No 1: 25 - 32

Setchell, K. D. R., \& Cassidy, A. 1999. Dietary isoflavones: biological effects and relevance to human health. The Journal of Nutrition, 129(3), 758S- 767S. https://doi.org/10.1093/jn/129.3. $758 \mathrm{~s}$

Wang, H. and P. A. Murphy. 1994. Isoflavone Content in Commercial Soybean Foods. J. Agric. Food Chem. 1994, 42, 1666 - 1673.

Yitnosumarto, S. (1993). Percobaan Perancangan, Analisis dan Interprestasinya. Yogyakarta: PT. Gramedia Pustaka Utama.

Zhu, D., Hettiarachchy, N., Horax, R., \& Chen P. 2005. Isoflavone Contents in Germinated Soybean Seeds. Plant Foods Human Nutrition, 60, 147-151

Adrinal. 2012. Perbaikan Sifat Fisiko Kimia Tanah. J. Solum Vol. 9 (1). Hal 25-32.

Albari J., Supijatno, dan Sudradjat, 2018. Peranan Pupuk Nitrogen dan Fosfor pada Tanaman Kelapa Sawit (Elaeis guineensis Jacq.) Belum Menghasilkan Umur Tiga Tahun. Bul. Agrohorti 6(1) : 42-49 (2018)

Alloway, B.J. (1995). Heavy Metal in Soils. 2nd Edition. New York:
Blackie Academic and

Professional-Chapman and

Hall.American Concrete

Institute.ACI Committee 226. (1988). Use of Fly Ash in Concrete. Farmington Hills, MI:

Charlena, 2004. Pencemaran Logam Berat Timbal $(\mathrm{Pb})$ dan Cadmium (Cd) pada Sayur-sayuran. Falsafah Sains. Program Pascasarjana S3 IPB. Posted tgl 30 Desember 2004. http:// www.google.co.id.

Damayanti R., 2018. Abu Batubara Dan Pemanfaatannya: Tinjauan Teknis Karakteristik Secara Kimia Dan Toksikologinya. Jurnal Teknologi Mineral dan Batubara Volume 14, Nomor 3, September $2018: 213$ 231.

Ekowati, Diah dan Mochamad Nasir. 2011. Pertumbuhan Tanaman Jagung (Zea mays L.) Varietas Bisi2 pada Pasir Reject dan Pasir Asli di Pantai Trisik Kulonprogo (The Growth of Maize Crop (Zea mays L.) BISI-2 Variety on Rejected and non Rejected Sand at Pantai Trisik Kulon Progo. J. Manusia dan Lingkungan, Vol. 18, No.3 : 220 231.

Ginting E.N., Hidayat F., dan Santoso H., 2011. Substitusi Pupuk MoP Dengan Tandan Kosong Kelapa Sawit Pada Perkebunan Kelapa Sawit Di Ultisol. Jurnal Penelitian Kelapa Sawit, Volume 19 No.1: 11 $-21$.

Goh, J.K., Hardter,R. 2010. General Oil Palm Nutrition. International Potash Institute Kassel. Germany.

Handayanto, E., Nuraini, Y,. Ichriani, G.Id., dan Fahrunsyah, 2017. Penggunaan Abu Terbang Batubara Dan Tandan Kosong Kelapa Sawit Untuk Meningkatkan 
Ketersedian Fosfor Pada Ultisol. Laporan Penelitian Universitas Brawijaya

Ikbal M., 2017. Meningkatkan ketersedian $\mathrm{P}$ pada tanah ultisol menggunakan batuan fosfat, bahan organik dan mikroba pelarut fosfat. Fakultas pertanian Universitas Hasanuddin Makassar.

Made Usman. 2010. Respons Berbagai Populasi Tanaman Jagung Manis (Zea mays saccharata Sturt.) terhadap Pemberian Pupuk Urea. J. Agroland 17 (2) : $138-143$.

Prasetyo, B.H. dan Suriadikarta, D.A. 2006. Karakteristik, potensi, dan teknologi pengelolaan tanah Ultisol untuk pengembangan pertanian di Inesia. Jurnal Litbang Pertanian 25(2):39-47.

Rosenani, A.B., S.Z. Darus, S. Kulaseharan, and N. Jamaluddin. 2010. Effects of ten year application of empty fruit bunches in an oil palm plantation on soil chemical properties. Journalof Springer

Suhendrayatna. 2001. Bioremoval Logam Berat dengan Menggunakan Mikroorganisme: Suatu Kajian Kepustakaan. Seminar On-Air Bioteknologi untuk Indonesia Abad 21. 1-14 Februari 2001.

Susanti D.M., dan Puspita F., (2017). Pemberian trichokompos tandan kosong kelapa sawit terformulasi terhadap pertumbuhan dan hasil tiga varietas bawang merah (Allium ascalonicum L.) di lahan gambut. Jurnal Photon Vol. 7 No. 2, Mei 2017.

https:/ / dspace.umkt.ac.id//handle /463.2017/537
Yang, X., Thor, ton P. E., Ricciuoto., D.M., and Post W. P. 2013. The Role of Phosphorus Dynamic In Tropical Forest-A Modeling Study Using CLM-CNP. Biogeosciences Discuss. 10: 14439-14473

Yulnafatmawita., Detafiano, D., Afner, P. and Adrinal. 2014. Dynamics of physical properties of Ultisol under maize cultivation in wet tropical area. International Journal on Advanced Science Engineering Information Technology 4 (5): 11 15. 
